\title{
PENGEMBANGAN LKPD BERBASIS COLLABORATIVE CREATIVITY UNTUK MENINGKATKAN CREATIVE THINKING SKILL PADA MATERI ASAM BASA
}

\section{THE DEVELOPMENT OF STUDENT'S WORKSHEET BASED ON COLLABORATIVE CREATIVITY TO IMPROVE CREATIVE THINKING SKILL ON ACID-BASE MATERIAL}

\author{
Refanny Anindya Fitria Hervyanti dan *Muchlis \\ Jurusan Kimia FMIPA Universitas Negeri Surabaya
}

e-mail: muchlis@unesa.ac.id

\begin{abstract}
Abstrak
Tujuan penelitian ini adalah menghasilkan LKPD Berbasis collaborative creativity untuk meningkatkan creative thinking skill pada materi asam basa yang layak digunakan. LKPD yang dikembangkan berdasarkan fase-fase collaborative creativity diantaranya (1) fase identifikasi masalah, (2) fase eksplorasi ide kreatif, (3) fase collaborative creativity, (4) fase elaborasi ide kreatif, dan (5) fase evaluasi hasil dan proses. Pengembangan LKPD ini meminta peserta didik untuk membentuk kelompok kerja kolaboratif yang terdiri dari kelompok kecil dan kelompok besar. Metode yang digunakan pada penelitian ini adalah Research and Development (R\&D) yang dibatasi sampai uji coba terbatas dengan 12 peserta didik kelas XII MIPA 11 SMAN 1 Sidoarjo. Kelayakan LKPD ditinjau dari tiga aspesk antara lain, aspek validitas, keefektifan, dan kepraktisan. LKPD dapat dikatakan valid apabila hasil persentase $\geq 61 \%$. Hasil penelitian menunjukkan bahwa LKPD yang dikembangkan layak digunakan berdasarkan aspek isi, penyajian, kebahasaan, dan kegrafikan dengan persentase berturut-turut 88,82\%; 90,94\%; $90 \%$; dan $90 \%$. Keefektifan ditinjau dari keterampilan berpikir kreatif peserta didik, hasil pretest dan posttest keterampilan berpikir kreatif dengan nilai N-Gain berkisar 0,6-0,8 dengan kategori tinggi. Peningkatan hasil pretest dan posttest didukung dari hasil observasi keterlaksanaan pembelajaran, observasi aktivitas peserta didik dengan persentase rata-rata berturut-turut 90,65\%; 95,45; dan. Kepraktisan LKPD ditinjau dari angket respon peserta didik dengan persentase $97 \%$ pada kategori sangat praktis.

Kata kunci: LKPD, collaborative creativity, keterampilan berpikir kreatif.
\end{abstract}

\begin{abstract}
This study aimed to obtain Student's Worksheet based on collaborative creativity to improve student's critical thinking on the acid-base material that is worth being used. The student's worksheet developed based on collaborative creativity phases, include (1) problem identification phase, (2) creative idea exploration phase, (3) collaborative creativity phase, (4) creative idea elaboration phase, and (5) result and process evaluation phase. This student's worksheet development demands students to make collaborative working groups consisting of small and big groups. The method used in this study is Research and Development (R\&D) method which was limited to limited trial with 12 students from Grade XII Natural Sciences 11 at Public Senior High School 1 Sidoarjo. The properness of Student's Worksheet viewed from three aspects; validity, effectiveness, and practicality aspects. The student's worksheet considered valid if the result of the percentage is $\geq 61 \%$. The research results showed that the developed student's worksheet is worth being used viewed from content, presentation, language, and graphical aspects with the percentage of $88.82 \%$; $90.94 \% ; 90 \%$; and $90 \%$, respectively. The effectiveness viewed from student's critical thinking, pre-test and post-test on creative thinking skill with $\mathrm{N}$-Gain value around 0.6-0.8 with the high category. The improvement of pre-test and post-test result was supported by the result of learning implementation and student activities observation with a successive average level of $99.65 \% ; 95.45 \%$. The practicality of student's worksheet viewed from students' response questionnaires at $97 \%$ of very practical.
\end{abstract}


Keywords: Student's Worksheet, Collaborative Creativity, Creative Thinking Skill.

\section{PENDAHULUAN}

Kimia merupakan ilmu pengetahuan yang terus berkembang berdasarkan observasi dan eksperimen, dalam proses pembelajarannya bertujuan untuk membentuk sikap ilmiah, memperoleh pengalaman dalam menerapkan pendekatan ilmiah dan menguasai konsep kimia serta kaitannya dengan pemecahan masalah di kehidupan sehari-hari [1]. Pendekatan ilmiah ini merupakan ciri dari K13. Komponen-komponen dari metode ilmiah diantaranya, observasi, inkuiri, uji coba, pengolahan, penyajian, menyimpulkan, dan mencipta sesuai Permendikbud No.69. Peserta didik dikatakan aktif dalam pembelajaran ketika dapat memahami konsep dan penerapannya [2]. Salah satu mata pelajaran kimia SMA adalah materi asam basa.

Materi asam basa tentunya sangat berkaitan dengan kehidupan sehari-hari, karena hampir setiap hari menggunakan bahan yang bersifat asam dan basa [3]. Materi pokok asam basa memiliki karakteristik materi berupa konsepkonsep dan fakta-fakta. Proses pembelajaran sampai saat ini masih belum sepenuhnya sesuai dengan kurikulum 2013, karena guru masih cenderung menggunakan cara konvensional yaitu ceramah, sehingga peserta didik kurang aktif yang menyebabkan keterampilan berpikir kreatif tidak dapat terbentuk saat proses pembelajaran berlangsung [4]. Guru lebih sering memberikan informasi yang sudah ada, seperti konsep atau rumus-rumus yang ada dibuku, kemudian memberikan contoh soal dan penyelesaiannya. Kebiasaan ini mengakibatkan peserta didik kesulitan memahami konsep kimia dan kurangnya keterampilan yang dimiliki peserta didik.

Abad ke-21 membutuhkan keterampilan berpikir keatif, kemampuan untuk mentransformasikan ide-ide baru menjadi beberapa kemungkinan pemecahan masalah [5]. Berdasarkan hasil pra-penelitian di SMAN 1 Sidoarjo pada hari Kamis, 15 Oktober 2020 dengan responden 65 peserta didik sebanyak $65,1 \%$ menyatakan bahwa materi kimia bersifat abstrak sehingga sulit dipahami. $46 \%$ peserta didik mengatakan asam basa merupakan salah satu materi kimia yang sulit dipahami, sebanyak 46\%, 73\% peserta didik menyatakan LKPD dapat membantu memahami materi selama proses pembelajaran, sedangkan keterampilan berpikir kreatif peserta didik tergolong rendah dengan perolehan hasil $41,67 \%$ pada indikator orisinality dan flexibility, 38,89\% pada indikator elaboration, $44,44 \%$ pada indikator fluency. Angket yang dihasilkan mendukung bahwa sebanyak $82,5 \%$ peserta didik lebih senang belajar menggunakan LKPD. Pencapaian kompetensi materi ini adalah mampu menjelaskan konsep asam dan basa serta kekuatannya dan kesetimbangan pengionannya dalam larutan.

Berdasarkan fakta tersebut untuk menunjang tercapainya kompetensi didukung dengan adanya sebuah keterampilan berpikir kreatif yang menunjang pemahaman konsep dengan baik dalam kegiatan belajar mengajar [6]. Keterampilan yang dapat membangun ide-ide baru untuk memecahkan masalah disebut keterampilan berpikir kreatif atau dapat disebut dengan berpikir divergen [7]. Keterampilan berpikir kreatif dapat dimiliki peserta didik dengan cara melibatkan langsung peserta didik dalam aktivitas kerja ilmiah untuk menyelesaikan suatu permasalahan.

Orisinalitas, kelancaran, fleksibilitas, dan elaborasi merupakan komponen berpikir kreatif [8]. Keempat indikator berpikir kreatif dapat dijelaskan sebagai berikut, (1) orisinality, mampu memperoleh ide-ide baru belum pernah ada, (2) fluency, mampu mendapatkan banyak ide, (3) flexibility, mampu memproduksi berbagai ide, dan (4) elaboration, mengacu pada kemampuan menguraikan ide untuk menghasilkan ide yang lebih detail.

Keterampilan berpikir kreatif peserta didik dapat dibentuk dengan melibatkan langsung peserta didik dalam kerja ilmiah. Hasil observasi menunjukkan peserta didik lebih mudah memahami materi kimia melalui kegiatan ilmiah [7]. Melaksanakan kegiatan ilmiah atau praktikum untuk meningkatkan pemahaman peserta didik dalam keterampilan berpikir kreatif. Analisis kondisional yang telah dilakukan, kegiatan ilmiah 
dapat melatih kemampuan berpikir kreatif peserta didik.

LKPD sebagai alat pendukung dalam kegiatan ilmiah. Kegiatan ilmiah dapat diselesaikan menggunakan LKPD sebagai pedoman bagi peserta didik untuk menemukan atau menentukan konsep [9]. LKPD merupakan sarana untuk membimbing peserta didik agar memiliki keterampilan berpikir kreatif.

LKPD berbasis Collaborative Creativity merupakan lembar kerja yang mengemukakan persoalan kehidupan sehari-hari yang dibahas setiap kelompok dengan menggali ide-ide kreatif, dan memecahkannya dengan menggabungkan ideide baru dari masing-masing individu hasil ide tersebut menjadi ide kelompok [10]. Faktor penting dari pembelajaran kolaboratif adalah adanya tujuan bersama dan rasa ketergantungan aktif di antara anggota kelompok [11]. Setiap peserta didik dapat memberikan ide kreatifnya untuk menyelesaikan permasalahan yang tersedia dalam LKPD. Berdasarkan penjabaran tersebut maka dikembangkan LKPD berbasis Collaborative Creativity untuk meningkatkan creative thinking skill pada materi asam basa.

\section{METODE}

Metode yang diterapkan pada penelitian adalah Research and Development (R\&D) dan dilakukan terbatas sampai uji coba. Tahapantahapan penelitian ditunjukkan pada Gambar 1 .

Penelitian ini diujikan pada 12 peserta didik dari kelas XII IPA 11 di SMA Negeri 1 Sidoarjo. Metode R\&D ini dilakukan dalam dua tahap, yaitu studi lapangan meliputi potensi, masalah, serta tahap mengembangkan produk antara lain pengambilan data, desain produk (draft I), telaah, produk (draft II), validasi produk, dan ujicoba [12]. Alat yang digunakan pada penelitian diantaranya lembar telaah, validasi, keterlaksanaan pembelajaran, lembar observasi aktivitas peserta didik, hasil respon peserta didik, dan tes keterampilan berpikir kreatif. kelayakan LKPD ditinjau dari aspek validitas, keefektifan, dan kepraktisan.



[12]

Gambar 1. Tahapan R\&D yang telah dimodivikasi

Data validasi ini dianalisis melalui penilaian dari LKPD yang dikembangkan. Setiap komponen dalam lembar validasi dianalisis. Validator mengevaluasi setiap komponen sesuai skala Likert pada Tabel 1.

Tabel 1. Skala Likert

\begin{tabular}{cc}
\hline Kategori Penilaian & Nilai Skala \\
\hline Sangat Sesuai & 5 \\
Sesuai & 4 \\
Cukup Sesuai & 3 \\
Kurang Sesuai & 2 \\
Tidak Sesuai & 1 \\
\hline
\end{tabular}

[13]

Perhitungan persentase menggunakan rumus sebagai berikut:

$$
\% \text { validasi }=\frac{\text { jumlah skortotal }}{\text { jumlah skor maksimum }} \times 100 \%
$$

Hasil dari rumus diatas dapat disimpulkan bahwa persentase evaluasi akan diinterpretasikan ke dalam penilaian validasi pada Tabel 2 .

Tabel 2. Persentase Penilaian Validasi

\begin{tabular}{cc}
\hline Persentase (\%) & kategori \\
\hline $0-20$ & Tidak valid \\
$21-40$ & Kurang valid \\
$41-60$ & Cukup valid \\
$61-80$ & Valid \\
$81-100$ & Sangat valid \\
\hline
\end{tabular}


LKPD dapat dikatakan valid digunakan jika hasil persentase mencapai $\geq 61 \%$ [14].

Hasil tes keterampilan berpikir kreatif di analisis untuk menentukan keefektifan LKPD. Data hasil tes keterampilan berpikir kreatif diperoleh dari soal pra-pembelajaran (pretest) dan posttest diakhir pembelajaran. Menganalisis peningkatan hasil pretest dan posttest melalui rumus $\mathrm{N}$-Gain (normalized gain). $\mathrm{N}$-gain menunjukkan hasil pencapaian skor pada saat tes dibandingkan dengan maksimum skor yang digunakan, nilai tersebut diperoleh dari analisis:

$\langle\mathrm{g}\rangle=\frac{\text { nilai posttest-pretest }}{100-\text { pretest }}$

Besarnya hasil peningkatan dari nilai Posttest dapat menghasilkan nilai yang diinterpretasikan ke dalam klasifikasi N-Gain pada Tabel 3.

Tabel 3. Klasifikasi N-gain

\begin{tabular}{cc}
\hline Rerata N-Gain & Klasifikasi \\
\hline N-Gain $\geq 0,7$ & Tinggi \\
$0,7>$ N-Gain $\geq 0,3$ & Sedang \\
$0,3>$ N-Gain & Rendah \\
\hline &
\end{tabular}

Berdasarkan kriteria tersebut, LKPD dapat dikatakan efektif digunakan jika N-Gain $\geq 0,3$ dengan kategori sedang.

Kelayakan LKPD pada aspek kepraktisan dapat dianalisis melalui angket respon peserta didik setelah dilakukan perlakuan LKPD yang dikembangkan dan dianalisis secara deskriptif. Skala Guttman pada Tabel 4 dapat digunakan untuk menghitung angket respon peserta didik.

Tabel 4. Kriteria Skala Guttman

\begin{tabular}{cc}
\hline Penilaian & Nilai Skala \\
\hline Ya & 1 \\
Tidak & 0 \\
\hline
\end{tabular}

[13]

Perhitungan yang digunakan untuk mengetahui respon peserta didik yaitu:

$$
\mathrm{P}(\%)=\frac{f}{N} \times 100 \%
$$

Keterangan:

$\mathrm{P}=$ Persen jawaban respon

$\mathrm{f}=$ jumlah jawaban "Ya"

$\mathrm{N}=$ Jumlah responden
Rumus ini dapat menghasilkan perkiraan persentase yang nantinya akan dijelaskan sebagai standar pada Tabel 5.

Tabel 5. Interpretasi Skor Respon Peserta Didik

\begin{tabular}{cc}
\hline Persentase (\%) & Kriteria \\
\hline $0-20$ & Tidak layak \\
$21-40$ & Kurang layak \\
$41-60$ & Cukup layak \\
$61-80$ & Layak \\
$81-100$ & Sangat layak \\
\hline
\end{tabular}

LKPD dikatakan layak digunakan bilamana respon peserta didik memenuhi kriteria layak dengan persentase $\geq 61 \%$.

\section{HASIL DAN PEMBAHASAN}

Bagian ini menguraikan hasil beserta pembahasan tentang penelitian pengembangan LKPD collaborative creativity. Research and Development (R\&D) yang terbatas pada tahap uji coba merupakan metode yang digunakan dalam pengembangan LKPD berbasis collaorative creativity . Pengambilan data dilakukan pada 16 Desember 2020 di SMAN 1 Sidoarjo kelas XII IPA 11. Data penelitian ini berupa validitas untuk mengetahui kelayakan LKPD, keefektifan LKPD ditinjau dari hasil observasi keterlaksanaan pembelajaran, hasil observasi aktivitas, dan hasil tes keterampilan berpikir kreatif peserta didik. Kepraktisan LKPD didapatkan dari hasil angket respon peserta didik.

\section{Tahap Studi Lapangan}

\section{Potensi dan masalah}

Peneliti menganalisis kondisi pembelajaran dan melakukan analisis kebutuhan di sekolah kemudian melakukan studi literatur untuk mengidentifikasi potensi dan masalah yang ada di sekolah. Studi literatur dilakukan dengan mencari referensi terkait LKPD, pendekatan Collaborative Creativity, keterampilan berpikir kreatif, dan materi asam basa.

\section{Pengumpulan Data}

Hasil wawancara dengan guru kimia dan penyebaran angket kepada peserta didik sebagai data pra penelitian yang dilakukan di SMA Negeri 1 Sidoarjo pada bulan Oktober 2020. 
Analisis angket yang telah dibagikan ke 65 responden tersebut didapatkan $73 \%$ peserta didik mengatakan bahwa LKPD dapat membantu memahami materi selama proses pembelajaran, yang tentunya dilengkapi dengan praktikum. Sehingga dari hasil angket tersebut perlu adanya pengembangan LKPD yang memuat indikator berpikir kreatif. LKPD yang dikembangkan berbasis Collaborative Creativity memiliki cara peserta didik diminta untuk berkelompok, bekerja dan berdiskusi. Kegiatan tersebut bermanfaat bagi peserta didik dalam bekerjasama dan berpikir kreatif.

\section{Tahap Perencanaan}

Hasil dari tahap ini adalah validasi perangkat pembelajaran berupa silabus dan RPP. Validasi silabus dan RPP dilakukan oleh 3 dosen kimia Unesa dan 1 guru kimia SMAN 1 Sidoarjo. Hasil validasi perangkat pembelajaran disajikan pada Tabel 6.

Tabel 6. Hasil Validasi Perangkat Pembelajaran

\begin{tabular}{|c|c|c|c|c|c|c|}
\hline \multirow{2}{*}{$\begin{array}{c}\text { Perangkat } \\
\text { yang } \\
\text { divalidasi }\end{array}$} & \multicolumn{4}{|c|}{ Skor } & \multirow{2}{*}{$\begin{array}{c}\text { Rata- } \\
\text { rata }\end{array}$} & \multirow{2}{*}{$\begin{array}{c}\text { Persentase } \\
(\%)\end{array}$} \\
\hline & $\overline{\mathrm{V} 1}$ & V2 & V3 & V4 & & \\
\hline Silabus & 24 & 29 & 28 & 30 & 27,8 & 92,5 \\
\hline RPP & 59 & 71 & 72 & 71 & 68,3 & 91 \\
\hline
\end{tabular}

Hasil validasi perangkat pembelajaran dikatakan valid apabila $\geq 61 \%$. Proses pembelajaran menggunakan LKPD collaborative creativity berada pada kategori sangat valid digunakan berdasarkan analisis validasi yang didapat.

Desain awal LKPD yang dikembangkan berdasarkan fase-fase collaborative creativity diantaranya (1) fase identifikasi masalah, sesuai petunjuk LKPD peserta didik dibagi menjadi kelompok kecil dan kelompok besar. (2) fase eksplorasi ide kreatif, kelompok kecil diminta membuat prediksi permasalahan yang nantinya didiskusikan dengan kelompok besar. (3) fase collaborative creativity, setelah melakukan pengamatan video percobaan kelompok kecil menuliskan data percobaan. (4) kelompok besar pada fase elaborasi ide kreatif diberi kesempatan untuk menganalisis data dengan menjawab pertanyaan yang tersedia di LKPD. (5) fase evaluasi hasil dan proses, bersama kelompok besar peserta didik diminta membuat sebuah kesimpulan dari percobaan yang telah diamati.

\section{Tahap Studi Pengembangan}

Pada tahap ini menghasilkan LKPD hasil dari revisi. Setelah mendapatkan telaah dari validator LKPD direvisi. Setelah dilakukan telaah yakni terdapat kekurangan pada beberapa fase dan indikator yang tidak sesuai sehingga perlu dilakukan revisi. Penelaah dan validator dari LKPD ini adalah tiga dosen Kimia Unesa dan satu guru Kimia SMAN 1 Sidoarjo, jika LKPD telah ditelaah dan divalidasi LKPD yang dikembangkan dapat digunakan untuk penelitian.

\section{Validitas LKPD}

Standart isi, penyajian, kebahasaan, dan kegrafikan digunakan sebagai penentu kelayakan LKPD yang dikembangkan berdasarkan persentase dengan masing-masing kriteria mencapai $\geq 61 \%$ [15]. Hasil validasi LKPD ditunjukkan pada Gambar 2.

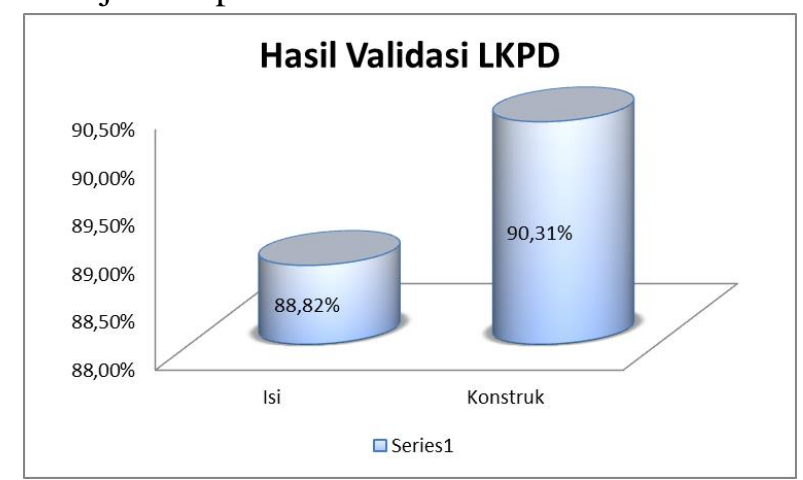

Gambar 2. Diagram Hasil Validasi LKPD

Validitas isi ditinjau dari beberapa komponen yang disesuaikan dengan KD yang terdapat dalam kurikulum 2013. Pada validitas isi terdapat kurangnya keterkaitan fenomena dengan tujuan yang akan mengarah ke memprediksikan suatu masalah dan kurangnya kesesuaian indikator dengan tujuan, sehingga diperlukan revisi setelah validasi. Berdasarkan diagram validasi LKPD menunjukkan persentase validitas isi sebesar $88,82 \%$ dengan kriteria valid.

Kesesuaian komponen LKPD dengan keterampilan berpikir kreatif didukung oleh teori belajar Piaget. Peserta didik dapat membangun pengetahuannya melalui pengalaman baru berdasarkan pengetahuannya, sehingga dapat 
memecahkan masalah dengan ide-ide kreatifnya [16]. Kompetensi menganalisis data pada LKPD, didukung oleh teori belajar Bruner dimana peserta didik belajar melalui percobaan sehingga dapat menemukan konsep baru [17].

Validitas konstruk LKPD didapatkan dari beberapa aspek yaitu, kriteria penyajian, kebahasaan, dan kegrafikan. Hasil dari validitas konstruk disajikan dalam Tabel 7.

Tabel 7. Hasil Validitas Konstruk

\begin{tabular}{lcc}
\hline \multicolumn{1}{c}{$\begin{array}{c}\text { Aspek } \\
\text { Kriteria }\end{array}$} & $\begin{array}{c}\text { Persentase } \\
(\mathbf{\%})\end{array}$ & Kategori \\
\hline Penyajian & $90,94 \%$ & Sangat valid \\
Kebahasaan & 90 & Sangat valid \\
kegrafikan & 90 & Sangat valid \\
\hline Diperlukan revisi & pada & aspek kebahasaan \\
dikarenakan beberapa kalimat tidak sesuai dengan \\
kemampuan peserta didik. LKPD collaborative \\
creativity dapat dikatakan valid atau layak \\
digunakan karena persentase yang didapatkan \\
dalam kisaran $81 \%-100 \%$ dalam kategori sangat \\
valid sehingga [13].
\end{tabular}

\section{Keefektifan}

\section{Keefektifan LKPD Collaborative}

Creativity dilihat dari hasil observasi pelaksanaan pembelajaran, hasil pengamatan aktivitas peserta didik dan nilai tes keterampilan berpikir kreatif peserta didik. LKPD yang dikembangkan dikatakan efektif jika berada pada kategori sedang-tinggi. Keterampilan berpikir kreatif bahwa berpikir kreatif menurut Torrance (1969) yang diambil dalam penelitian ini melibatkan unsur-unsur orisinility, fluency, fleksibilitas, dan elaboration [8].

Keterlaksanaan pembelajaran ditinjau dari kegiatan selama pembelajaran berlangsung dimana guru mengajar sesuai sintaks Collaborative Creativity yang diamati oleh 2 pengamat. Data hasil keterlaksanaan pembelajaran dapat dilihat dalam Tabel 8 berikut :

Tabel 8. Hasil Observasi Pelaksanaan Pembelajaran

\begin{tabular}{ccccccc}
\hline & \multicolumn{4}{c}{ Aspek yang Diamati (\%) } & Rata- \\
\cline { 2 - 6 } & A & B & C & D & E & rata (\%) \\
\hline P1 & 87,5 & 87,5 & 87,5 & 93,8 & 93,8 & 90,02 \\
P2 & 93,8 & 87,5 & 93,8 & 87,5 & 93,8 & 91,28 \\
\hline
\end{tabular}

Rata-rata keterlaksanaan pembelajaran sebesar 90,65\% dengan kriteria sangat baik berdasarkan data pada Tabel 8. Setiap fase sudah terlaksana meskipun dalam penerapannya kurang sempurna. Analisis hasil obeservasi keterlaksanaan pembelajaran dapat diartikan bahwa guru (peneliti) dalam pengelolaan pembelajaran di kelas sangat baik, dengan demikian LKPD berbasis collaborative creativity layak digunakan untuk pembelajaran dengan melatih keterampilan berpikir kretif peserta didik. Keterlaksanaan pembelajaran juga dinilai dari aktivitas peserta didik sesuai dengan sintaks Collaborative Creativity. Tabel 9 menyajikan data hasil pengamatan aktivitas peserta didik.

Tabel 9. Hasil Pengamatan Aktivitas Peserta Didik

\begin{tabular}{|c|c|c|c|c|c|c|}
\hline & \multicolumn{5}{|c|}{ Aktivitas yang Diamati (\%) } & \multirow{2}{*}{$\begin{array}{c}\text { Rata- } \\
\text { rata } \\
(\%)\end{array}$} \\
\hline & $\mathbf{A}$ & B & $\mathbf{C}$ & D & $\mathbf{E}$ & \\
\hline P1 & 91,8 & 91,8 & 95,8 & 91.8 & 100 & 94,24 \\
\hline P2 & 95,8 & 100 & 95,8 & 91,8 & 100 & 96,66 \\
\hline
\end{tabular}
peserta didik dalam pembelajaran diperoleh dari pengamatan oleh 2 pengamat menggunakan lembar aktivitas peserta didik. Penilaian aktivitas peserta didik bertujuan untuk mengetahui aktivitas peserta didik selama proses pembelajaran berlangsung menggunakan LKPD yang dikembangkan. Aktivitas peserta didik meningkat dari pembelajaran 1 ke pembelajaran 2 dengan persentase rata-rata $95,45 \%$ dan termasuk kategori efektif. Setiap peserta didik sudah mengikuti pembelajaran dengan aktif dan terlibat langsung dalam mengerjakan LKPD yang dikembangkan. Fase-fase collaborative creativity diantaranya (A) identifikasi masalah, sesuai petunjuk LKPD untuk membentuk kelompok kecil dan kelompok besar sendiri dan mengamati suatu masalah. (B) eksplorasi ide kreatif, kelompok besar mendiskusikan permasalahan yang telah diprediksi dengan kelompok kecil. (C) collaborative creativity, bersama kelompok kecil peserta didik melakukan pengamatan video percobaan lalu menuliskan data hasil percobaan. (D) elaborasi ide kreatif, peserta didik menjawab pertanyaan yang tersedia di LKPD dengan kelompok besar berdasarkan analisis data yang 
diperoleh. (E) fase evaluasi hasil dan proses, bersama kelompok besar peserta didik diminta membuat simpulan dari percobaan yang telah diamati.

Fase elaborasi ide kreatif pada penelitian ini lebih rendah dibandingkan dengan fase-fase keterampilan berpikir kreatif lainnya. Data hasil percobaan dianalisis dengan menjawab pertanyaan pada LKPD collaborative creativity. Pembelajaran berjalan kurang maksimal dikarenakan untuk menganalisis data yang didapatkan dibutuhkan waktu yang cukup lama. Kegiatan penyelidikan ilmiah dapat membantu peserta didik untuk menyelesaikan suatu permasalahan. Kegiatan penyelidikan ilmiah sesuai dengan teori Piaget, peserta didik dapat membangun pemahamannya dari pengalaman baru berdasarkan pengetahuannya sehingga dapat memecahkan masalah dengan ide-ide.

Kegiatan kolaborasi yang dilakukan antara peserta didik satu dengan yang lainnya akan memberikan pengalaman, pengetahuan dan pendekatan hidup untuk mencapai tujuan pembelajaran. Pembelajaran melalui kegiatankegiatan yang ada di dalam LKPD yang dikembangkan dan disesuaikan dengan sintaks dari model collaborative creativity membuat peserta didik aktif berpartisipasi selama pembelajaran [18]. LKPD yang dikembangkan berdasarkan model collaborative creativity sesuai dengan kurikulum 2013 meliputi kegiatan mengamati, menyelidiki, mengeksplorasi, mengasosiasi, dan mengkomunikasikan yang menekankan peserta didik aktif selama pembelajaran [19].

Kemampuan awal peserta didik dapat diketahui dengan memberikan Pretest sebelum pembelajaran dilakukan. Posttest diberikan sesudah peserta didik melakukan pembelajaran menggunakan LKPD collaborative creativity untuk meningkatkan keterampilan berpikir kreatif. Pembelajaran menggunakan LKPD berbasis collaborative creativity dilakukan sebanyak dua kali. Peserta didik diminta untuk mengerjakan posttest untuk mengetahui kemampuan peserta didik setelah pembelajaran dengan LKPD berbasis collaborative creativity dalam keterampilan berpikir kreatif. Kategori dalam nilai N-Gain digunakan untuk mengetahui peningkatan keterampilan berpikir kreatif peserta didik. Ketika peserta didik memahami materi pelajaran, maka hasil tes setelah diberikan LKPD yang dikembangkan akan menunjukkan hasil yang maksimal [20]. LKPD yang dikembangkan dikatakan efektif jika nilai rata-rata $\mathrm{N}$-Gain minimal $(0,3<(\mathrm{g}) \leq 0,7)$ pada kategori sedang. Analisis hasil pretest dan posttest peserta didik disajikan dalam Tabel 10.

Tabel 10. Hasil pretest dan posttest

\begin{tabular}{lcccc}
\hline \multirow{2}{*}{ Nama } & Kriteria & \multicolumn{2}{c}{$\begin{array}{c}\text { Keterampilan } \\
\text { berpikir kreatif }\end{array}$} & $\begin{array}{c}\text { n-gain } \\
\text { Skor }\end{array}$ \\
\cline { 3 - 4 } & & Pretest & Postest & \\
\hline AA & Tinggi & 55,55 & 88,88 & 0,75 \\
AFR & Tinggi & 44,44 & 88,88 & 0,8 \\
DSI & Tinggi & 44,44 & 88,88 & 0,8 \\
GMF & Sedang & 44,44 & 77,77 & 0,6 \\
GEY & Tinggi & 55,55 & 88,88 & 0,75 \\
HAZH & Tinggi & 66,66 & 88,88 & 0,6 \\
MSA & Sedang & 44,44 & 77,77 & 0,6 \\
WNP & Tinggi & 44,44 & 88,88 & 0,8 \\
SDKS & Sedang & 44,44 & 77,77 & 0,6 \\
RPI & Tinggi & 44,44 & 88,88 & 0,8 \\
HGPN & Tinggi & 55,55 & 88,88 & 0,75 \\
SAMS & Tinggi & 44,44 & 88,88 & 0,8 \\
\hline \multicolumn{2}{c}{ Data hasil } & tes keterampilan & berpikir
\end{tabular}

kreatif didapatkan N-Gain skor berkisar 0,6-0,8 pada sangat tinggi, LKPD yang dikembangkan layak digunakan karena menunjukkan peningkatan keterampilan berpikir kreatif pada materi asam basa. Peserta didik sangat antusias saat pembelajaran berlangsung, dengan begitu materi yang disampaikan lebih mudah diterima.

LKPD collaborative creativity efektif digunakan untuk meningkatkan keterampilan berpikir kreatif peserta didik karena menunjukkan peningkatan dari hasil pretest dan posttest. Penelitian yang sebelumnya dilakukan mengantakan bahwa kreativitas peserta didik dapat dilatihkan melalui model collaborative creativity [18]. Pembelajaran collaborative creativity mampu meningkatkan kemampuan berpikir kreatif peserta didik. Hasil analisis pretest dan posttest berada dalam kategori tinggi, sehingga pembelajaran menggunakan LKPD berbasis collaborative creativity membantu meningkatkan keterampilan berpikir kreatif. Soal 
pretest dan posttest yang digunakan disesuaikan pada LKPD yang dikembangkan. Dengan demikian peserta didik mampu menjawab soal dan hasil peningkatan nilai sebelum dan sesudah penerapan LKPD yang dikembangkan lebih baik dibanding penelitian sebelumnya.

Indikator keterampilan berpikir kreatif dianalisis untuk melihat tercapainya keterampilan dilatihkan tersebut. Keterampilan berpikir kreatif peserta didik dapat dilihat dari proses pembelajaran saat menggunakan LKPD berbasis collaborative creativity. LKPD yang dikembangkan dibagikan ke masing-masing kelompok kecil dan kelompok besar untuk dikerjakan. Keterampilan berpikir kreatif dilihat dari proses pembelajaran saat menggunakan LKPD yang dikembangkan. Tabel 11 menyajikan analisis indikator keterampilan berpikir kreatif.

Tabel 11. Hasil Analisis Keterampilan Berpikir Kreatif

\begin{tabular}{|c|c|c|c|c|c|}
\hline \multirow[t]{2}{*}{ Kelompok } & \multicolumn{4}{|c|}{ Indikator (\%) } & \multirow{2}{*}{$\begin{array}{c}\text { Rata- } \\
\text { rata } \\
(\%)\end{array}$} \\
\hline & $\mathbf{A}$ & B & $\mathrm{C}$ & D & \\
\hline 1 & 91,8 & 87,5 & 91,3 & 82,5 & 82,28 \\
\hline 2 & 91,8 & 88,3 & 89,8 & 84,8 & 88,68 \\
\hline 3 & 93,5 & 88 & 93,8 & 85,5 & 90,2 \\
\hline
\end{tabular}

Indikator berpikir kreatif yang dilatihkan

yaitu (A) orisinality, (B) flexibility, (C) elaboration, dan (D) fluency. LKPD yang dikembangkan dikatakan efektif melatihkan keterampilan berpikir kreatif. Kreativitas peserta didik dapat ditingkatkan dengan model pembelajaran collaborative creativity [23]. LKPD yang dikembangkan dapat membantu peserta didik untuk meningkatkan keterampilan berpikir kreatif serta melaksanakan kegiatan kerja ilmiah dan membimbing peserta didik untuk berpikir kreatif dari identifikasi masalah, eksplorasi, collaborative creativity, elaborasi ide kreatif sampai evaluasi proses dan hasil.

\section{Kepraktisan}

Analisis angket respons peserta didik digunakan untuk meninjau kepraktisan LKPD collaborative creativity. Lembar angket respons peserta didik merupakan alat yang digunakan untuk menilai LKPD yang dikembangkan termasuk dalam kategori praktis atau tidak. Kriteria kepraktisan ditinjau dari mudah tidaknya produk yang dikembangkan dan dipahami oleh pengguna [21]. Menurut kriteria interpretasi skor keterlaksanaan, pembelajaran LKPD collaborative creativity dapat dikatakan praktis karena persentase yang dihasilkan $\geq 61 \%$.

Lembar angket respon dibagikan ke 12 peserta didik untuk memberikan tanggapan setelah menggunakan LKPD asam basa. Gambar 3 menjelaskan hasil angket respons peserta didik.



Gambar 3. Hasil Respons Peserta Didik

Respons peserta didik yang dinilai antara lain: (1) Menurut saya desain LKPD ini menarik, (2) Menurut saya LKPD ini menggunakan bahasa yang mudah dimengerti, (3) Pertanyaan dalam LKPD ini dirumuskan dengan jelas, (4) LKPD yang telah dikembangkan membantu saya untuk lebih memahami konsep asam basa sub bab kekuatan asam basa, (5) LKPD yang telah dikembangkan membantu saya dalam melatih proses berpikir, (6) Saya termotivasi untuk melakukan kegiatan percobaan, (7) Saya tertarik melakukan pembelajaran dengan LKPD ini, (8) LKPD ini mampu menghubungkan materi kimia dengan kehidupan sehari-hari, (9) LKPD ini dapat melatih kemampuan saya untuk mengidentifikasi pertanyaan ilmiah dalam percobaan, (10) LKPD ini dapat melatih kemampuan saya untuk memprediksi suatu permasalahan, (11) LKPD ini dapat melatih kemampuan saya menganalisis data eksperimen, (12) LKPD ini dapat melatih kemampuan saya untuk menarik kesimpulan dalam eksperimen, dan (13) keterampilan berpikir kreatif saya meningkat dengan bantuan LKPD ini. Respon peserta didik sangat baik untuk desain, materi, pertanyaan atau 
masalah yang terdapat di dalam LKPD dapat memupuk rasa ingin tahu dan semangat belajar berdasarkan nilai rata-rata angket respon [22]. Gambar 3 diperoleh persentase rata-rata sebesar 97\% yang artinya LKPD yang dikembangkan masuk dalam kategori sangat praktis untuk digunakan dalam kegiatan pembelajaran [13].

\section{SIMPULAN}

kesimpulan:

Hasil analisis dan pembahasan didapatkan

1. Validitas LKPD berbasis collaborative creativity dinyatakan valid atas kriteria isi mendapat persentase $88,82 \%$, penyajian 90,94\%, kebahasaan 90\%, dan kriteria kegrafisan $90 \%$ dengan masing-masing kategori sangat valid.

2. Keefektifan LKPD dikatakan efektif ditinjau dari observasi pelaksanaan pembelajaran (persentase rata-rata $90,65 \%$ ), observasi aktivitas peserta didik (rata-rata persentase 95,45\%), peningkatan N-Gain skor ditunjukkan dari hasil pretest dan posttest keterampilan berpikir kreatif yang berkisar 0,6-0,8 dalam kategori tinggi.

3. Angket respon peserta didik digunakan untuk meninjau kepraktisan LKPD persentase ratarata yang dihasilkan $97 \%$ termasuk kategori praktis sekali.

\section{SARAN}

Berdasarkan analisis data dan simpulan, saran agar pengembangan penelitian selanjutnya akan lebih baik antara lain,

1. LKPD berbasis collaborative creativity diberi waktu yang lama pada fase elaborasi ide kreatif karena pada fase elaborasi ide kreatif persentase yang dihasilkan lebih rendah dibandingkan pada fase-fase keterampilan berpikir kreatif lainnya.

2. Komponen keterampilan berpikir kreatif fluency mendapat rata-rata skor paling rendah jika dibandingkan dengan komponen yang lain, penelitian selanjutnya sebaiknya guru memperhatikan dan lebih membimbing peserta didik dalam mengerjakan soal saat membuat kesimpulan yang diperoleh lebih maksimal.

\section{DAFTAR PUSTAKA}

1. Mulyasa, E. 2007. Menjadi Guru Profesional menciptakan Pembelajaran Kreatif dan Menyenangkan. Bandung: Rosdakarya.

2. Kemendikbud. 2016. Permendikbud No.20 Tahun 2016 Tentang Standar Kompetensi Lulusan Pendidikan Dasar dan Menengah. Jakarta: Mendikbud.

3. Noviati, F. D., \& Muchlis. 2018. Penerapan Model Pembelajaran Kooperatif Tipe Number Heads Together (NHT) untuk Melatihkan Keterampilan Komunikasi Siswa pada Materi Asam Basa Kelas XI SMA Negeri 11 Surabaya. Unesa Journal Chemical Education, Vo.5 No.2.

4. Oktavina, Romafika., \& Suliyanah. 2020. Melatihkan Keterampilan Berpikir Kreatif Peserta Didik dengan Menggunakan LKPD berbasis Collaboratife Creatvity. Jurnal Inovasi Pendidikan Fisika (JIPF). Vol.09 No. 01.

5. Lailiyah, Qifiyatul., \& Suliyanah. 2018. Profil Keterampilan Berpikir Kreatif Ilmiah Siswa pada Materi Momentum dan Impuls Kelas XI SMA Negeri 1 Tarik Sidoarjo. Jurnal Inovasi Pendidikan Fisika (JIPF). Vo.1 07 No. 01.

6. Munandar, Utami. 2009. Pengembangan Kreativitas Anak Berbakat. Jakarta: Rineka Cipta.

7. Turkmen, dan Sertkahya, Mehmet. 2015. Creative Thinking Skills Analize of Vocational High School Students. Journal of Educational and Instructional Studies. Vol.5.

8. Torrance, E. P. 1969. Creativity What Researc Says to the Teacher. Washington DC: National Education Association.

9. Guyotte, K., N. W. Sochacka, T. E. Costantino, dan N. N. Kellam. 2015. Collaborative Creativity in STEAM: Narratives of Art Education Students' Experiences in Transdiciplinary Spaces. International Journal of Education \& the Arts. Vol.16 No.15. 
10. Setyawati, N. I., \& Suliyanah. 2018. Profil Pengembangan Lembar Kerja Peserta Didik (LKPD) berbasis Guided Discovery untuk melatihkan Keterampilan Proses Sains Peserta Didik pada Materi Getaran Harminis di MA Negeri Sidoarjo. Jurnal Inovasi Pendidikan Fisika (JIPF). Vol. 07 No. 02.

11. Astutik, S., E. Susanti, dan Madlazim. 2017. Model Pembelajaran Collaborative Creativity untuk Meningkatkan Afektif Kolaboratif Ilmiah dan Kreativitas Ilmiah Peserta didik pada Pembelajaran IPA. Jurnal Inovasi Pendidikan Fisika (JIPF). Vol. 07 No. 02.

12.Sugiyono. 2009. Metode Penelitian Pendidikan (Pendekatan Kualitatif, Kuantitatif, dan $R \& D)$. Bandung: Alfabeta.

13. Riduwan. 2015. Skala Pengukuran Variabelvariabel Penelitian. Bandung: Alfabeta.

14. Hake, R. R. 1998. Interactive Engagement Versus Traditional Methods: A Six Thousand Student Survey of Mechaindes Test Data for Introductory Physics Courses. American Journal Phisics, Vol. 66, No. 1.

15. Plomp, Tjeerd \& Nieveen, Nienke. 2010. An Introducing to Educational Design Research. Enschede, The Netherlands: Netherlands Institute for Curriculum Development.

16. Kamilasari, Nur Wandiyanah, Astutik, Sri dan Nuraini, Lailatul. 2019. Model Pembelajaran Collaborative Creativity (CC) berbasis SETS terhadap
Kemampuan Berpikir Kreatif pada Pembelajaran Fisika. Seminar Nasional Pendidikan Fisika. ISSN: 2527-5917, Vo. 4 No. 1.

17. Dahar, R. Wills. 2011. Teori-teori belajar dan pembelajaran. Jakarta: Erlangga.

18. Astuti, Sri., Binar, 2018. The Practicality and Effectiveness of Collaborative Creativity Learning (CCL) Model by Using PhET Simulation to Increase Students Scientific Creativity. International Journal of Intruction. Vol. 11 No. 4.

19.Depdiknas. 2013. Peraturan Menteri Pendidikan dan Kebudayaan Nomor 69 Tahun 2013 Tentang Kerangka Dasar dan Struktur Kurikulum Sekolah Menengah Atas/Madrasah Aliyah. Jakarta: Badan Standar Nasional Pendidikan.

20. Slavin, R. E. 2011. Psikologi Pendidikan. Jakarta: PT Indeks.

21. Nieven, Nienke dan Tjeen Plomp. 2010. An Introduction to Education Design Research Edisi Ketiga. Enschede: Netzodruk.

22. Prastowo, A. 2015. Panduan Kreatif Membuat Bahan Ajar Inovatif. Yogyakarta: DIVA Press.

23. Astutik, S., Mohamad Nur, dan Susiani Endang. 2017. Validity of Collaborative Creativity (CC) Model. Proceeding of $3^{R D} \quad$ International Conference on Researc, Implementation and Education of Mathematics and Science. ISBN 978602-74529-0-9. 